\title{
Origin of S-, A- and I-Type Granites: Petrogenetic Evidence from Whole Rock Th/U Ratio Variations
}

\author{
Anette Regelous $^{1, *}$, Lars Scharfenberg ${ }^{2}$ (D) and Helga De Wall ${ }^{1}$ \\ 1 GeoZentrum Nordbayern, Friedrich-Alexander-Universität Erlangen-Nürnberg, Schlossgarten 5, \\ 91054 Erlangen, Germany; helga.de.wall@fau.de \\ 2 Institut für Geologie, Universität Wien, Althanstr. 14, 1090 Wien, Austria; lars.scharfenberg@univie.ac.at \\ * Correspondence: anette.regelous@fau.de; Tel.: +49-8526065
}

Citation: Regelous, A.; Scharfenberg, L.; De Wall, H. Origin of S-, A- and

I-Type Granites: Petrogenetic

Evidence from Whole Rock Th/U Ratio Variations. Minerals 2021, 11, 672. https://doi.org/10.3390/ $\min 11070672$

Academic Editor: José

Francisco Molina

Received: 27 May 2021

Accepted: 17 June 2021

Published: 24 June 2021

Publisher's Note: MDPI stays neutral with regard to jurisdictional claims in published maps and institutional affiliations.

Copyright: (c) 2021 by the authors. Licensee MDPI, Basel, Switzerland. This article is an open access article distributed under the terms and conditions of the Creative Commons Attribution (CC BY) license (https:/ / creativecommons.org/licenses/by/ $4.0 /)$.

\begin{abstract}
The origin and evolution of granites remain a matter of debate and several approaches have been made to distinguish between different granite types. Overall, granite classification schemes based on element concentrations and ratios, tectonic settings or the source rocks (I-, A-, S-type) are widely used, but so far, no systematic large-scale study on Th/U ratio variations in granites based on their source or tectonic setting has been carried out, even though these elements show very similar behavior during melting and subsequent processes. We therefore present a compiled study, demonstrating an easy approach to differentiate between S-, A- and I-type granites using Th and $U$ concentrations and ratios measured with a portable gamma ray spectrometer. Th and $U$ concentrations from 472 measurements in S- and I-type granites from the Variscan West-Bohemian Massif, Germany, and 78 measurements from Neoproterozoic A-type Malani granites, India, are evaluated. Our compendium shows significant differences in the average Th/U ratios of A-, Iand S-type granites and thus gives information about the source rock and can be used as an easy classification scheme. Considering all data from the studied A-, I- and S-type granites, Th/U ratios increase with rising Th concentrations. A-type granites have the highest Th/U ratios and high Th concentrations, followed by I-type granites. Th/U ratios in S- to I-type granites are lower than in A-type and I-type granites, but higher than in S-type granites. The variation of Th/U ratios in all three types of granite cannot be explained by fractional crystallization of monazite, zircon and other Th and $U$ bearing minerals alone, but are mainly due to source heterogeneities and uranium mobilization processes.
\end{abstract}

Keywords: granites; uranium; thorium; continental crust; petrogenesis

\section{Introduction}

Granitoid rocks dominate the upper and middle continental crust $([1,2]$ and references therein). Despite the wide distribution and intense research, the origin of granitic rocks is still a matter of debate ([3,4] and references therein). It is widely believed that many granites are a result of fractional crystallization of mantle-derived basaltic magmas, even in active continental margin settings (e.g., [5,6]). Alternatively, granites are thought to be products of partial melting of middle-lower crustal protoliths, during orogenesis and crustal thickening or thinning [7-14].

The ongoing discussion shows that it is difficult to decipher the petrogenesis of granite formations. Obviously, there are several variables that control the magma composition, such as pressure, temperature, volatiles, source rocks and potentially tectonic setting. To make things even more complicated, the magma composition is subsequently modified by assimilation, fractional crystallization and mixing processes. A reliable tracer that is not altered by subsequent processes after the melting process would provide information about the source rock of the granite and the petrogenetic processes leading to magma generation. A very common method found in the literature is the use of tectonic discrimination diagrams in which trace element concentrations and their ratios and $\mathrm{Rb} / \mathrm{Sr}$ and $\mathrm{Sm} / \mathrm{Nd}$ 
isotope ratios give information about the tectonic setting. However, these diagrams are controversially discussed, because at the time of their development, the complexity of tectonic evolution was still unknown [15].

Crust formation can be a multi-stage process, thought to occur in at least two stages, because felsic melts are not in equilibrium with mafic and ultramafic rocks [16]. In a first stage, basaltic magmas are produced by partial melting of the mantle; in a second stage, either fractional crystallization or re-melting of the basalt produces the more evolved rocks of which the upper-middle continental crust is dominantly composed. The products may then undergo further differentiation by one or more cycles of re-melting [16-18]. Therefore, the upper-middle continental crust has been produced throughout Earth history by mantle extraction and is mostly composed of granitoid rocks [2,19-21]. The thickness of the granitic upper crust is estimated to range between $10-20 \mathrm{~km}$ [22-24].

In the field, granitoid rocks are normally classified after Le Maitre $[25,26]$ based on their chemical variability and after Streckeisen [27] based on their relative modal proportions of quartz, alkali feldspar and plagioclase. The scheme from Shand [28,29] is based on the chemical composition, in which granites are either peraluminous, metaluminous, or peralkaline. Peraluminous rocks have an excess of $\mathrm{Al}_{2} \mathrm{O}_{3}$ over that required to crystallize feldspar and have an alumina-saturating phase; metaluminous rocks are deficient in alumina relative to the alkalis and lime, whereas peralkaline granites are deficient in $\mathrm{Al}_{2} \mathrm{O}_{3}$ relative to the alkalis. However, this scheme has the disadvantage that it gives not always a distinct petrogenetic link. The most common used geochemical classification scheme is that of Chappell and White [30,31], which subdivides granites into (a) I-type, product from an igneous or intracrustal source, (b) S-type, product of anatexis of metasedimentary or supracrustal protoliths, (c) A-type, which are alkaline, anhydrous, and/or anorogenic such as cratons or rift zones and (d) M-type mantle-like granites (e.g., [32-36]). Other types (Hand C-) have been also proposed but these classes are not widely used [37,38]. However, this classification of granitic rocks has been criticized [34,39] as it assumes a simple source for granitic rocks, which is probably oversimplifying. Nonetheless, to our understanding, this descriptive classification is still the best one, given that different types of granitic rocks are, in general, characteristic for different tectonic settings.

$\mathrm{U}$ and Th concentrations as well as Th/U ratios are useful parameters in the characterization of granitic rocks (e.g., [23]). Granites have high concentrations of $U$ and Th [40]. However, Th and $U$ concentrations vary significantly within crustal rocks as a result of petrogenetic processes responsible for their formation [41]. U and Th are incompatible elements during melting of mantle rocks, as they have large ionic radii and high valence, which prevents them from being incorporated into the structure of the main rock-forming minerals and are enriched in felsic/crustal rocks [41,42]. Th and U occur mostly in accessory minerals, such as zircon, apatite, monazite, titanite, xenotime and allanite within igneous and metamorphic rocks and thus show only a weak correlation with $\mathrm{SiO}_{2}$ and thus fractional crystallization trends (e.g., [43-45]]. However, in some I-type granites Th and $\mathrm{U}$ contents increase with differentiation, i.e., $\mathrm{SiO}_{2}$ contents (e.g., [46,47]). Similarly, Th decrease and $U$ increase with differentiation in some S-type granites, especially in phosphorous-rich suites (e.g., [48]). Th and $\mathrm{U}$ are transported to the middle and upper crustal levels through several different processes associated with high-grade metamorphism, metasomatism, partial melting, and fluid and melt migration [49]. During partial melting and crystal fractionation, Th and $\mathrm{U}$ are preferentially fractionated into the silicate melt and, over time, these elements have been enriched in the Earth's continental crust. Geochemical models predict a global mean ratio for Th/ $\mathrm{U}=3.7-4.0$ for the bulk Earth and primitive mantle [49]. Globally, the average Th/ $\mathrm{U}$ ratio of the continental crust is estimated to be about 4 [40,50-52], with a significant variability reported for the continental crust $[2,51,53-55]$. Th and $U$ behave very similar, because they are both tetravalent species in the mantle, and therefore, difficult to fractionate significantly by melting processes. In contrast, under more oxidized surface conditions, the elements show contrasting behavior, with Th remaining tetravalent and immobile during weathering, unlike highly water- 
soluble hexavalent U species [56]. Bea et al. [57] showed, in a study about metapelites in the Ivra-Verbano Zone, that $U$ was compared to Th enhanced into the fluid phase that was released at the end of crystallization of leucosomes. On the other hand, studies from Variscan I- and S-type granites from central Spain show that Th/U ratios can also be affected by fractionation $[47,48]$, as the Th concentrations are influenced by this process.

So far, a systematic global study on Th and $\mathrm{U}$ concentrations and ratios in order to distinguish between different types of granites has not been carried out. This is therefore the first systematic Th and U study of S-, A-, and I-type granites on a larger scale, including 550 measurements. Here we present data from the western Bohemian Massif comprising I-type to S-type granites and NW India with vast exposure of A-type granites. We here show that average Th/U ratios vary significantly between S-, I-, and A-type granites and that $\mathrm{Th} / \mathrm{U}$ ratios and concentrations can be used to distinguish between petrogenetic processes leading to the formation of granitic rocks. This implies that the variation of $\mathrm{Th} / \mathrm{U}$ ratios in all three types of granite cannot be explained by fractional crystallization of monazite, zircon and other Th- and U-bearing minerals alone, but is mainly due to source heterogeneities and additionally, in some S-type granites due to uranium mobilization processes.

\section{Geological Settings}

\subsection{I- and S-Type Variscan Granites along the Western Bohemian Massif}

The granites studied here are representative for Variscan intrusions [58,59] and cover the Fichtelgebirge (Saxothuringian Zone), the Oberpfalz area (transition zone between Saxothuringian and Moldanubian Zone) and the Bavarian Forest (Moldanubian Zone) (Figure 1). For a wider context of the European Variscan chains, see e.g., [57,60-63].

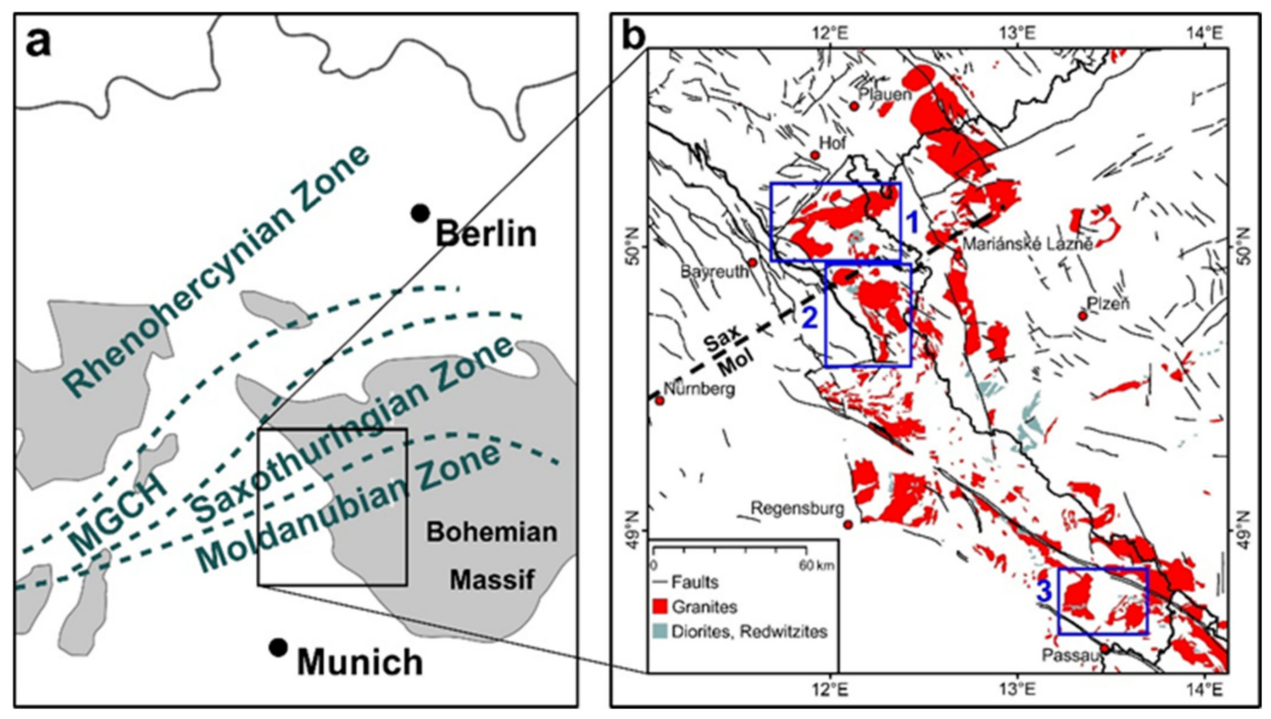

Figure 1. Location of the sampling sites from the Bohemian Massif. Region 1-Fichtelgebirge; region 2-Oberpfalz; region 3-Bavarian Forest.

The granites intruded in late-Variscan time expanding a period of about 40 m.y. $[59,64,65]$ whereby the geochemical characteristics allow a subdivision into two granite suites, known as older intrusive complex (OIC) and younger intrusive complex (YIC), respectively. The Fichtelgebirge and Oberpfalz granites are peraluminous S- to I-type granites that formed through anatexis of metasediments in middle or deep levels of the crust.

Quartz-monzodiorites (locally named redwitzites) are the precursors of the granites in the Fichtelgebirge and Oberpfalz area. They are predominately metaluminous and interpreted as I-type granites, which represent melting of crustal rocks triggered and mixed 
with mantle-derived melts $[59,64,66]$. These diorites represent the initial phase of the late orogenic intrusions at about $323 \mathrm{Ma}$ [64].

Zircon geochronology in NE Bavaria indicates simultaneous intrusion of the diorites and the spatially associated older granites in regions 1 and 2 [64]. Co-existence of the diorites and the older granites as contemporaneous but different magmas may suggest that there was also a link between melt extraction from the mantle, heat input into the crust, and the generation of diorites and larger amounts of well-mixed homogeneous older granites melts [64]. Formation of the younger granites, at 328-320 Ma, 315-312 Ma and $298 \mathrm{Ma}$, marks the time when pure, intracrustal, acidic S-type magmas were produced [65]. The granites are classified as monzogranites and their geochemical characteristics reach from weakly peraluminous biotite-granites to moderate and strongly peraluminous \pm biotite muscovite granites, e.g., [65].

The Bavarian Forest (region 3) is part of the Moldanubian Zone and high-grade regional metamorphism is recorded in this internal part of the Variscan orogeny ( 340 Ma, [67]). In contrast to the above described regions 1 and 2, the Bavarian Forest exposes a deeply eroded middle to lower continental crust [68]. Depth of granite intrusion has been constrained at 16 to $18 \mathrm{~km}$ for the Hauzenberg Pluton [69]. Regional high temperature metamorphism associated with migmatization and anatexis of Moldanubian rock associations in the Bavarian Forest is constrained at 326-322 Ma $[68,70]$ and formation of major granite complexes are related to these processes. This includes the Hauzenberg and Fürstenstein intrusive complexes. Granodiorites are similar to the diorites of the Fichtelgebirge and are I-type granitoids, while granites from these complexes are classified as S-type granites $[69,71]$.

The granites of this area have been the subject of various geochemical studies (e.g., $[72,73])$. Compared with the granites from the worldwide granite database GRANITE2017 [23], the studied granites are typical for S-, I- and S- to I-type granites. Data on radioelement concentration have been obtained from in situ gamma radiation measurements, reported in previous studies [74,75].

\subsection{A-Type Malani Granites}

The late-Neoproterozoic Malani Igneous Suite (770-750 Ma) [76] is one of the largest felsic igneous provinces and exposed in scattered outcrops in NW India to SE Pakistan [77-80] (Figure 2). 


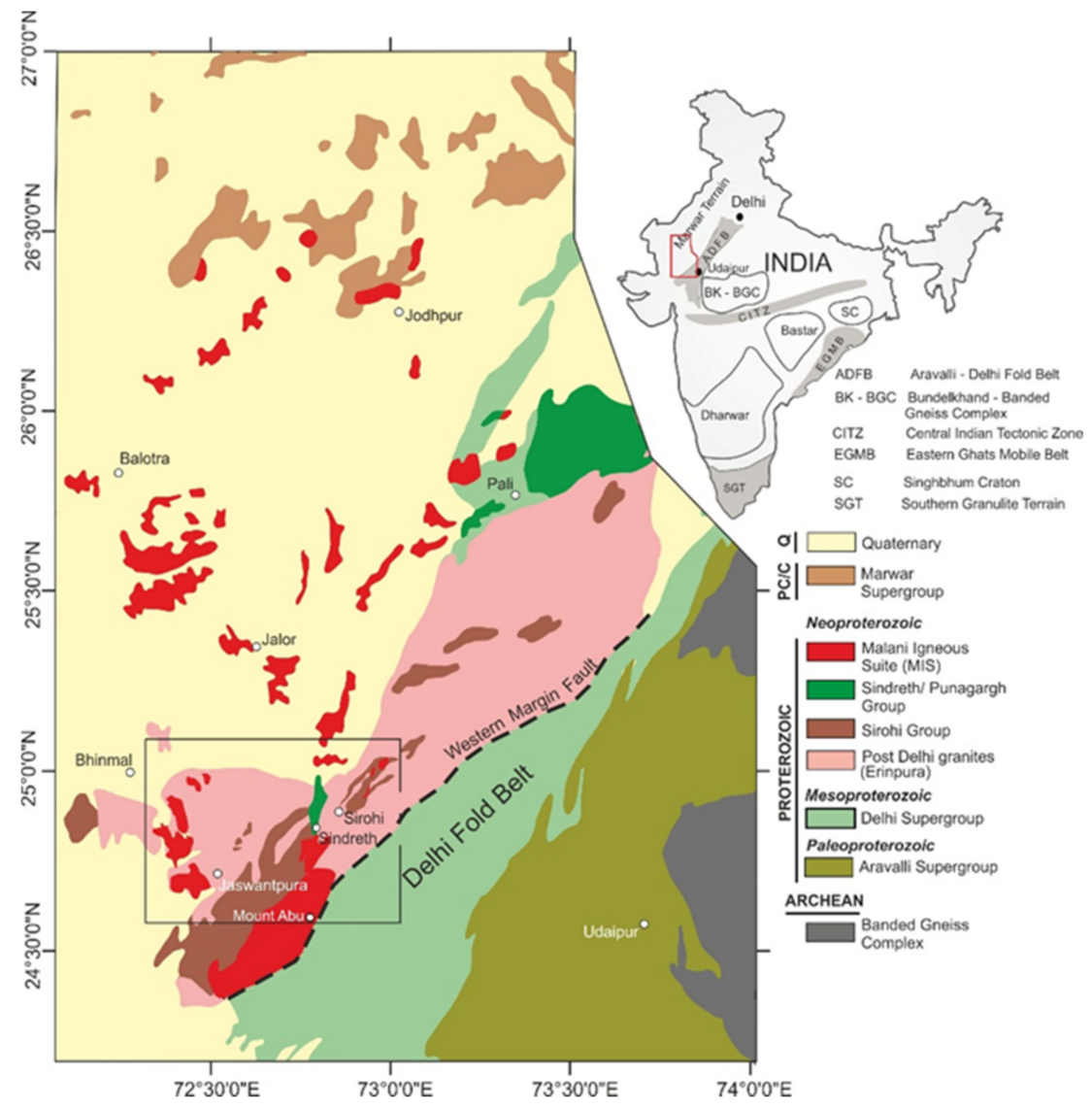

Figure 2. Location of the Malani samples from India. Measured samples are from within the frame. Geological map after [81]. Coordinates of the sample locations can be found in [74,75].

The Malani granites were formed by the anatexis of an older Neoproterozoic granitic crust (Erinpura granites, see [82]). The granites are peraluminous to metaluminous and classified as A-type (e.g., [83]). Compared with the granites from the worldwide granite database GRANITE2017 [23], the Malani granites are typical A-type.

Felsic rocks of the Malani Igneous Suite are well known for their high radiogenic heat production [84]. The Malani granites are characterized by high but varying Th and $\mathrm{U}$ concentration [85]. Some intrusions such as granites forming the Mt. Abu batholith reach Th content of $>100 \mathrm{ppm}$ and $\mathrm{U}$ of up to $20 \mathrm{ppm}[79,86]$.

\section{Methods}

We use Th and $\mathrm{U}$ concentrations measured with a portable gamma ray spectrometer RS 230 manufactured by Radiation Solutions, Ontario, Canada. It uses a bismuth germinate (BGO) scintillation detector. Individual data (550 samples) and coordinates of locations are all recorded in our previous published papers $[74,75]$, but can also be found in Table S1. We provide statistical evaluation in Table S2 and statistical analysis using the Mann-Whitney pairwise U-test with Bonferroni correction (Past 4.01) in Table S3 (see Supplementary Materials). Measurements were taken in the "assay-mode" over a $120 \mathrm{~s}$ interval. The device integrates an area of about $1 \mathrm{~m}$ in diameter with a depth of about $15-25 \mathrm{~cm}$ when in direct contact with the outcrop. The manufacturer used concrete pads of $1 \mathrm{~m} \times 1 \mathrm{~m} \times 30 \mathrm{~cm}$ size containing known amounts of potassium, uranium and thorium and a fourth pad with none of these three elements to measure the background for calibration of the instrument, as described in [87]. Possible cross interferences can occur, as error components for a single element will also influence the remaining elements (Radiation Solutions, Ontario, Canada) [87]. For a detailed description and comparison with ICP-MS analyses, see [74]. 


\section{Results}

\section{Malani Granites}

The concentrations of the Malani granites vary between 20 and $100 \mathrm{ppm}$ and $\mathrm{U}$ concentrations vary between 1 and $20 \mathrm{ppm}$ (Figure $3 \mathrm{a}, \mathrm{b}$ ). Average Th and $\mathrm{U}$ concentrations of the Malani granites are $47.7 \mathrm{ppm} \pm 2.1$ for Th and $7.6 \mathrm{ppm} \pm 0.4$ for U. Mt. Abu Malani A-type granites show higher average Th and $\mathrm{U}$ concentrations with $68.5 \mathrm{ppm} \pm 5.1$ for Th and $8.5 \mathrm{ppm} \pm 0.6$ for $\mathrm{U}$, respectively.
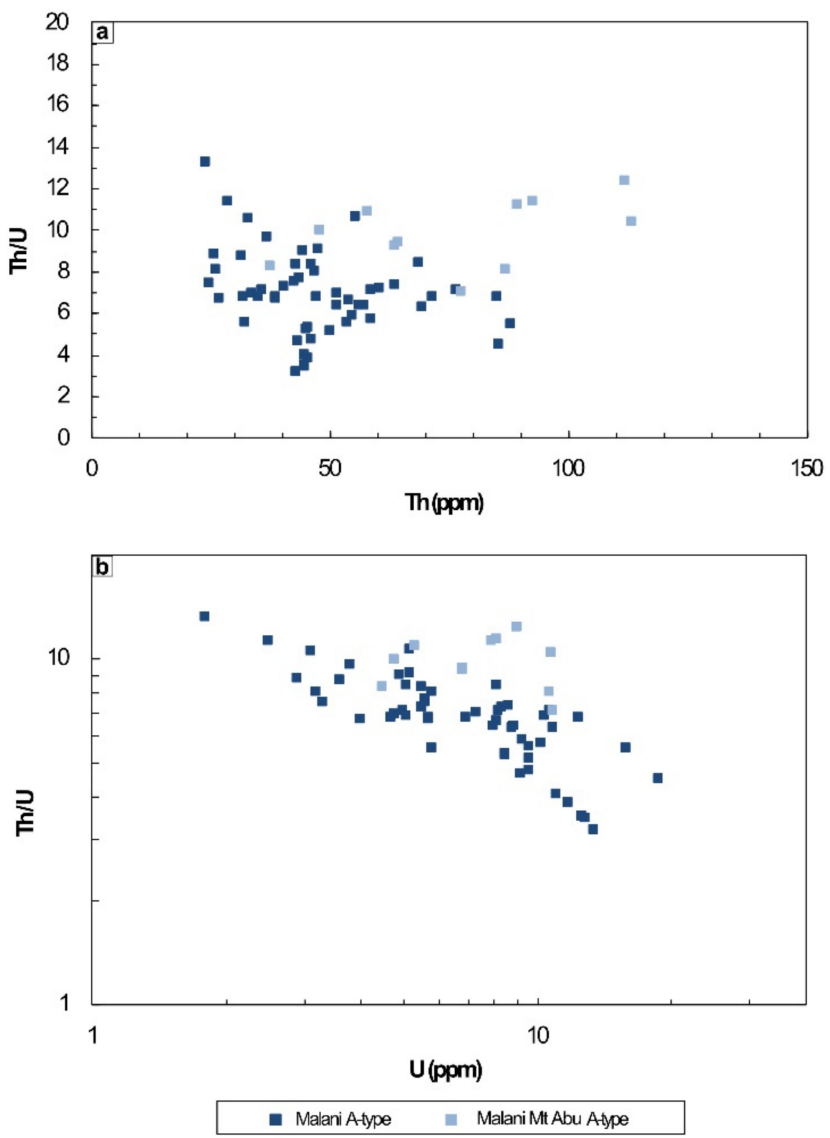

Figure 3. Th/U versus Th (a) and Th/U versus $\mathrm{U}(\mathbf{b})$ for the Malani A-type granites.

\section{Variscan Granites}

The uranium concentrations of the Fichtelgebirge (7 ppm to $34 \mathrm{ppm}$ ) and the Bavarian Forest (4 ppm to $20 \mathrm{ppm}$ ) are quite similar. Compared to the two other regions, the Oberpfalz intrusives have a much greater variation to high values (8-61 ppm U). YIC granites tend to have higher $\mathrm{U}$ concentrations than the OIC granites. The Th content in all granites is $<40 \mathrm{ppm}$ (Figures 4-6). 

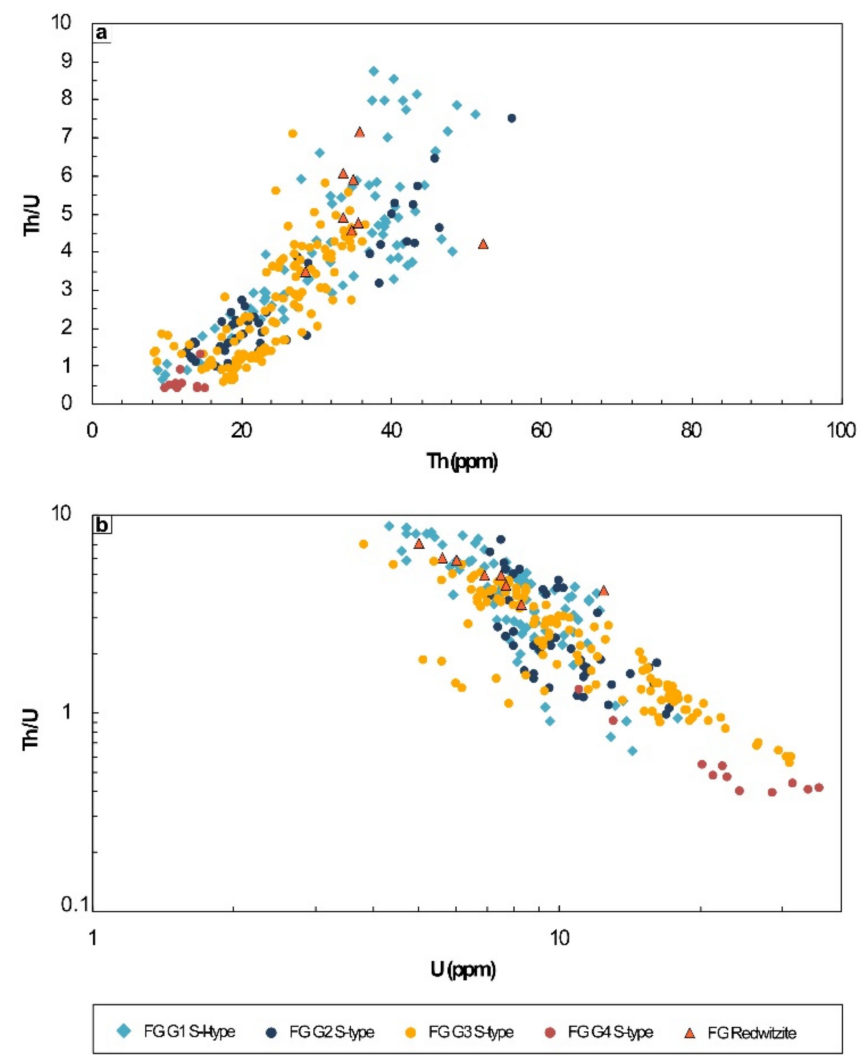

Figure 4. Th/U versus Th (a) and Th/U versus $U$ (b) for the Fichtelgebirge granites and diorites.
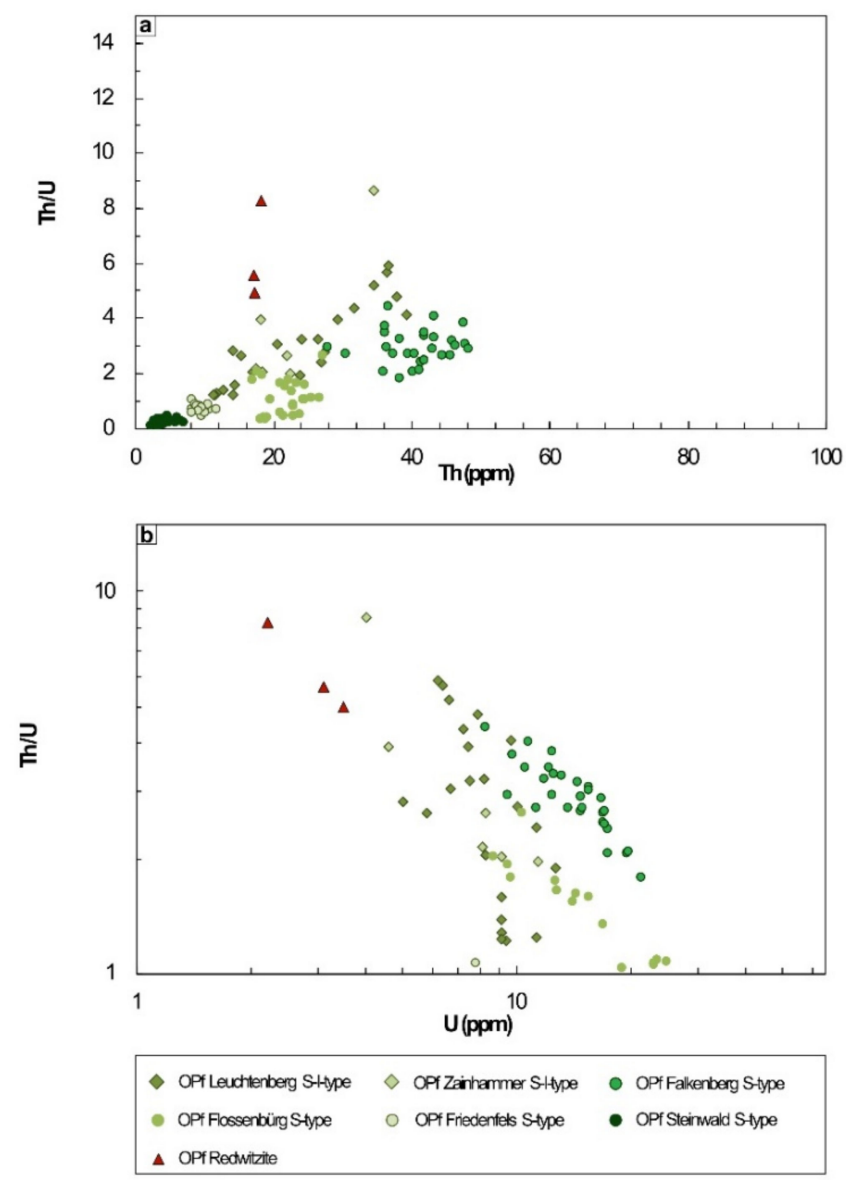

Figure 5. Th/U versus Th (a) and Th/U versus $U$ (b) for the Oberpfalz granites and diorites. 

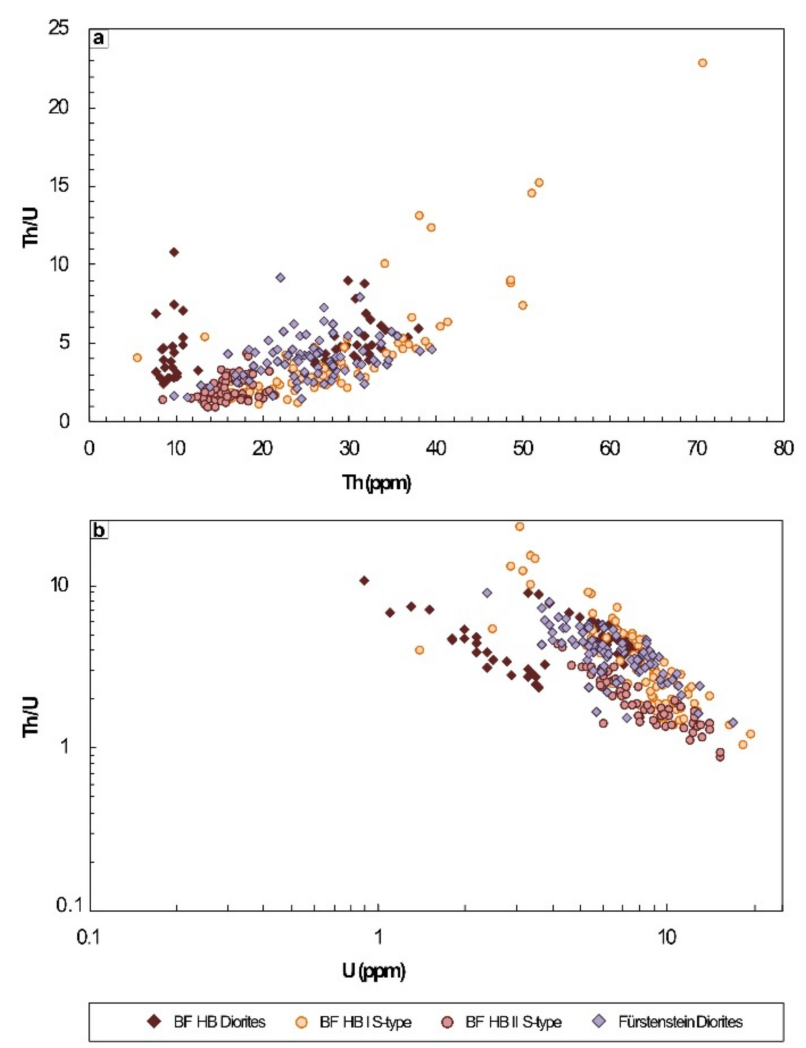

Figure 6. Th/U versus Th (a) and Th/U versus $U$ (b) for the granites and diorites of the Bavarian Forest.

Comparison between the Different Types of Granite

In general, the A-type granites tend to have higher Th concentrations compared to the other granite types, followed by I-type granites (Figure 7). A-, I- and S-type granites all lie on an L-shaped Th versus U concentration line. The Malani A-type granites have the highest $\mathrm{Th}$ concentrations and $\mathrm{Th} / \mathrm{U}$ ratios. Th concentrations are lower in S- to I-type granites compared to A-type and I-type granites, but they have higher Th values than the S-type granites. S-type granites have the highest $U$ and lowest Th concentrations These observations are supported by statistical evaluation (Table S2 in the Supplementary Materials) and statistical analysis, using the Mann-Whitney U-test with Bonferroni correction (Past 4.01) (Table S3 in the Supplementary Materials). The statistical analysis show that the Th concentrations differ significantly for all granite types at the $95 \%$ confidence interval. The $\mathrm{U}$ concentrations differ significantly for all granite types except S-I-type and A-type granites at the $95 \%$ confidence interval.

S-type granites with highest $\mathrm{U}$ and lowest $\mathrm{Th}$ concentrations have been shown from the Iberian Variscan granites, too [48].

Calculated averages of Th and U concentrations of A- and I- and I- to S-type granites all fall within the field for Th/U $>1$, but the S-type granites lie partly in the Th/U $>1$ and partly in the Th/U $<1$ field (Figure 8 ). Overall, the average Th concentrations vary between $4.5 \mathrm{ppm}$ and $68.5 \mathrm{ppm}$, the average $U$ concentrations between 2.9-27.8 ppm. The I-type granites plot nearest to the average continental crust [88]. 


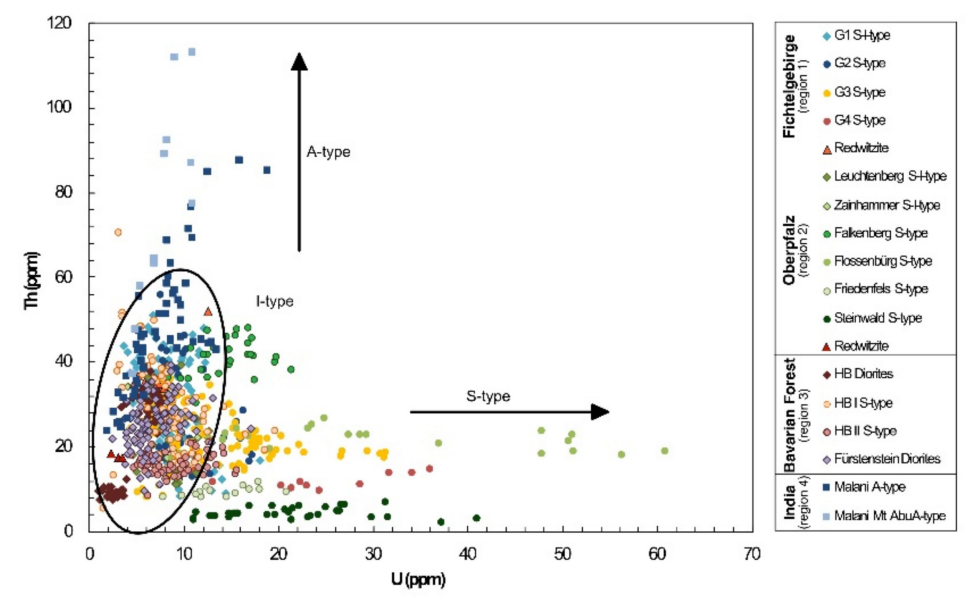

Figure 7. Th versus $U$ concentrations for all samples. Th and $U$ concentrations show a large range, even within individual regions. However, A-type granites tend to have higher Th concentrations, I-type granites have moderate concentrations (marked with the ellipse) and S-type granites tend to have higher U concentrations. Abbreviations: FG: Fichtelgebirge (Region 1), OPf: Oberpfalz (Region 2), BF: Bavarian Forest (Region 3), HB: Hauzenberg, MIS: Malani Igneous Suite, gamma-ray data from in situ measurements of gamma radiation [75]; MIS A-type geochemical data: U and Th values from geochemical analyses from the Mt. Abu batholith $[79,86]$.

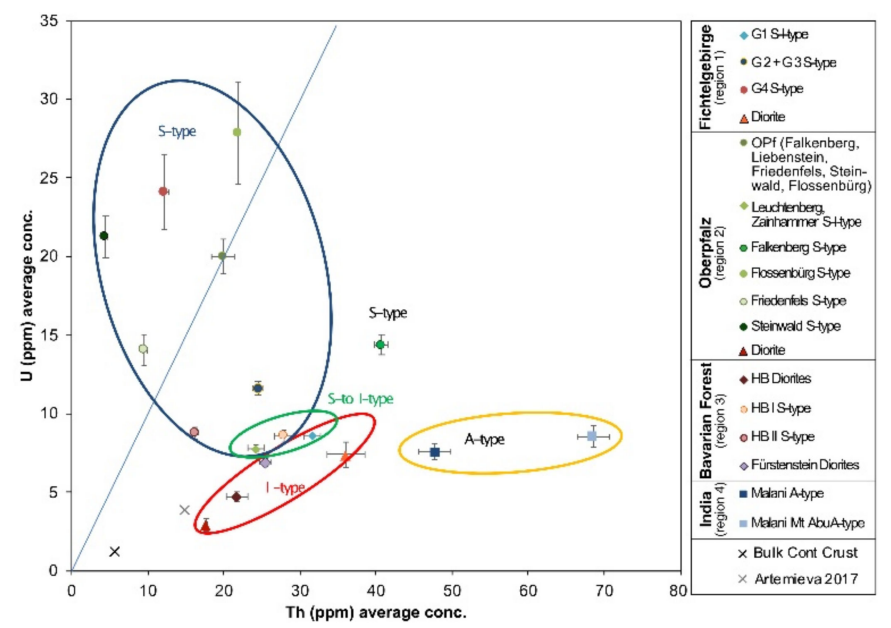

Figure 8. Average Th and U concentrations of the different granites and diorites from this study. Bulk continental crust from [2,23]. All A- and I- and I- to S-type granites fall within the field for Th/U $>1$, but the S-type granites lie partly in the Th/U $>1$ and partly in the Th/U $<1$ field. Data and statistical analysis are given in Tables S1-S3 in the Supplementary Materials.

The Th/U ratios display a large variation from 0.08 to 15 (Figure 9) and considering all data, Th/U ratios rise with increasing Th concentrations. The medians of the Th/U ratios differ significantly for the different granite types at the $95 \%$ confidence level, with the exception of the S-I-type and I-type medians, which only differ at the $90 \%$ confidence interval (see Table S3 in the Supplementary Materials). The S-type granites show the lowest $\mathrm{Th} / \mathrm{U}$ ratios, followed closely by the S- to I-type granites. The I-type granites have higher $\mathrm{Th} / \mathrm{U}$ ratios and the A-type granites have the highest Th/U ratios. In the Th/U versus $\mathrm{U}$ diagram (Figure 10), the samples show a negative line. The S-type granites have higher and quite variable $U$ concentrations with different $T h / U$ ratios. The average continental crust has Th/U ratio of 4 [50] just as the I-type granites. 


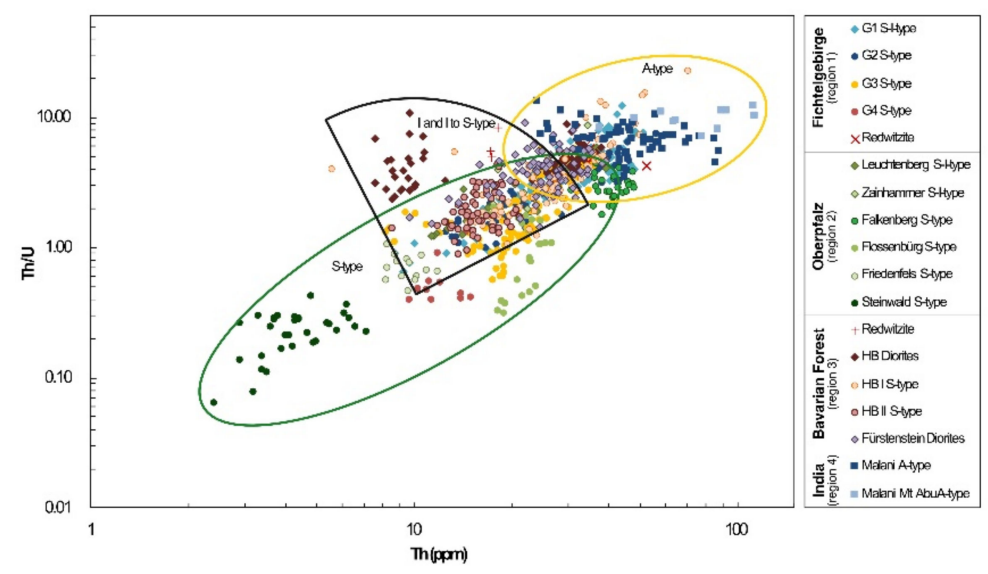

Figure 9. Th/U versus Th for all samples. Considering all data, increasing Th concentrations correlate with increasing Th/U ratios. The S-type granites show the lowest average Th/U ratios, followed closely by the S- to I-type granites. The I-type granites have, on average, higher Th/U ratios and the A-type granites, on average, the highest $\mathrm{Th} / \mathrm{U}$ ratios.

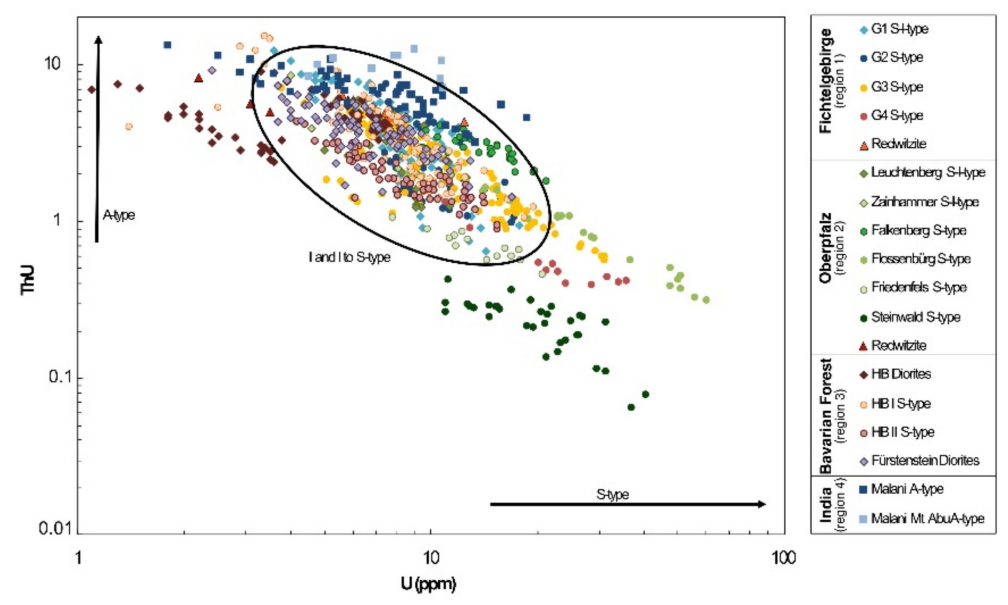

Figure 10. Th/U versus $U$ for all samples. The samples show a negative line. The A-type granites tend to raise the Th/U ratios. The S-type granites show higher and quite variable $\mathrm{U}$ concentrations with lower $\mathrm{Th} / \mathrm{U}$ ratios.

\section{Discussion}

\subsection{Systematic A-, I-, and S-Type Th/U Ratios and Concentrations in Granites}

Our aim is to investigate how granite types of different tectonic settings correlate with Th and $U$ concentrations and Th/U ratios. Artemieva et al. [23] argued that $U$ and Th concentrations as well as $\mathrm{Th} / \mathrm{U}$ ratios are useful tools for the characterization of granitic rocks. They also showed that the geodynamic environment for the generation of granites might have changed through the early Earth history and speculated that after the Middle Proterozoic, the production of granites occurred in more diverse tectonic settings, which led to an increase in the diversity of Th and $U$ concentrations [23]. Within the continental crust, Th and $U$ concentrations show a large variation [2,51,53-55] and even within rock types, or at pluton scale, the Th and $U$ concentrations vary considerably $[41,89]$. Adams et al. [90] proposed that differences within rock types are commonly greater than the average differences between the various igneous rock types. The granite database GRANITE2017 [23] reports mean Th concentrations of $14.8 \pm 13.2 \mathrm{ppm}$ and mean U concentrations of $3.93 \pm 3.27 \mathrm{ppm}$ in granites. However, such Th and $\mathrm{U}$ concentrations are significantly lower compared to most granites of this study and we therefore suggest that the Th and $U$ variation is even larger than previously thought (Figure 7). The database GRANITE2017 reports Th/U ratios that are in the range of the predicted global mean 
ratio of $\mathrm{Th} / \mathrm{U}=(3.7-4.0)$ for the bulk Earth and primitive mantle [49] and is in agreement with the average $\mathrm{Th} / \mathrm{U}$ ratio of the continental crust of about four [2,40,50-52,91], with variations reported from individual plutons [2,51,53-55]. Thus, in contrast to the Th and $\mathrm{U}$ concentrations, the Th/U ratios in granitoids are believed to be rather constant $[41,92]$, but vary from 3.8 [51] to 5.2-5.3 [53,55]. However, these results rely on a relatively small number of systematic regional Th and U studies, e.g., for some A-type (e.g., [93] and I- and S-type granites (e.g., [30,31], but similar global studies are absent for different granite types and for granitic rocks in general. Exceptions are reported for some I- $[46,47]$ and S-type granites [48], and references therein. This study covers systematic regional Th/U ratio analysis of A-, I- and S-type granites of Malani, Fichtelgebirge, Oberpfalz and the Bavarian Forest. The Th/U ratios of all four regions show a large range between 0.07-12.4 (Figure 3a, Figure 4a, Figure 5a, and Figure 6a). Artemieva et al. [23] proposed that only granites of the Archean and Early Proterozoic have Th/U ratios $>10$. However, the here presented Malani A-type granites show that granites younger than the Early Proterozoic can also have Th/U ratios $>10$. A-type granites have higher $\mathrm{Th} / \mathrm{U}$ ratios and Th concentrations compared to the other granite types. This implies a Th-enriched source, which might have developed during earlier small-scale partial melting processes in the mantle over a prolonged time.

On the other hand, many S-type granites show high U concentrations and low Th/U ratios. In addition, nearly all samples have $\mathrm{Th} / \mathrm{U}$ ratios $>1$, except most S-type granites from the Oberpfalz region that lie along a suture zone in which the Th/U ratios $<1$ are due to U mobilization (Figure 8). This is associated with carbon-rich sedimentary units and mobilization during hydrothermal processes [94-96]. The Flossenbürg intrusion has very high $U$ concentrations. The long axis of the oblong shape of this intrusion parallels lateVariscan faults and such setting might favor the mobilization of U. Fluid mobilization can change the $U$ concentrations, but does not affect the Th concentrations (e.g., [97-99]. This is because $U$ is far more mobile because of its increased solubility at higher oxidation states, whereas Th has only one valence state and remains inside the lattice sites of the minerals. Although in S-type granites of the Oberpfalz region, $U$ mobilization is more likely, as hydrothermal processes did take place in wide areas of these intrusions, the involvement of fractional crystallization in some P-rich S-type granites has also been invoked for explaining their low Th/U ratios. The chemical variation of magmatic phosphates of those Variscan granites (monazite, xenotime, see [48], apatite, see [100]) evolves within each granite unit, generating in the most fractionated one the (Th-poorest) U-richest accessories ever described in granites: up to $23 \mathrm{wt} \% \mathrm{UO}_{2}$ in monazite, up to $13 \mathrm{wt} \% \mathrm{UO}_{2}$ in xenotime [48] and up to 460 ppm $U$ in apatite [100].

Thus, large Th/U ratio variation can be explained by different source compositions / tectonic settings, degree of melting, fractional crystallization and late-stage U mobilization. The positive Th/U versus Th trend line together with the $U$ and $T h$ concentrations show that the variation in Th/U ratios is mostly dependent of Th, except in the cases of $U$ mobilization.

\subsection{Why Do the Th/U Ratios Vary within One Region?}

Assuming that granites are not derived from a simple source, each intrusion should show a unique Th/U ratio depending on the source composition. It is therefore inevitable to have a closer look at some individual plutons.

$\mathrm{U}$ and Th concentrations of all studied granites-except the $U$ concentrations of Steinwald-are higher than the estimated values for the bulk continental crust (1.3 ppm U and $5.6 \mathrm{ppm}$ Th) [2]. In general, high $U$ and Th concentrations can be explained by the presence of monazite and zircon in granites. Fractionation of monazite lowers both the $\mathrm{Th} / \mathrm{U}$ ratio and the Th concentration as monazite has high Th concentrations. In contrast, zircon fractionation does not affect the Th concentration much, but lowers the Th/U ratio, as zircon incorporates more $U$ than Th. Monazite hosts more than $80 \%$ of Th in all studied rocks [101]. The importance of zircon for Th and $U$ in the rock budget in granites is lower, ranging from $4-26 \%$ for $U$ and less than $5 \%$ for Th. The study of [101] showed 
that for the peraluminous granite plutons of the Bohemian Massif granites of similar mineral composition, they contain zircon and monazite of different chemistry and no simple proportional relationship exists between the chemical composition of magma and the chemistry of accessory mineral phases crystallized from the melt. The concentration of minor elements in monazite and zircon are strongly influenced by the order of their crystallization [101]. It is therefore doubtful to only use the chemical composition of accessory minerals for a geochemical interpretation of parental granites.

Malani Granites

A-type Malani granites have Th and $U$ concentrations well above the average given by [23] in GRANITE2017 for granites and Th concentrations increase with rising U concentrations (Figure $3 \mathrm{a}, \mathrm{b}$ ). Th/U ratios are mainly controlled by the $\mathrm{U}$ contents, as $\mathrm{Th} / \mathrm{U}$ versus $\mathrm{U}$ diagram shows a weak negative data correlation whereas $\mathrm{Th} / \mathrm{U}$ versus Th only shows a data cluster (Figure 3a,b). These patterns define a typical trend of fractional crystallization in felsic magmas with slightly more zircon fractionation compared to monazite. The correlation of Th and $U$ concentrations indicate that secondary fluid mobilization has not played a major role in the Malani granites.

Mt. Abu Malani granites show higher average Th/U ratios and higher average $\mathrm{U}$ and Th concentrations compared to the Malani granites. In the Th/U versus Th diagram, the samples show a slight positive correlation; in the Th/U versus $U$ diagram, the samples show a cluster. This implies that, in this case, the zircon fractionation was not dominant compared to the monazite fractionation. Together with previous research, this suggests that the Mt. Abu Malani granites have the same source as the Malani granites, but a lower degree of melting or a higher degree of fractionation [79]. Both processes would support the model of emplacement of several magma batches to form this large intrusion of approximately $125 \mathrm{~km}^{2}[79,86]$.

Variscan Granites

The Variscan granites show increasing Th/U ratios with rising Th concentrations and a negative line on the plot of Th/U versus $U$ (Figures 4-6). The positive trend in Th/U versus Th suggests that the sources of the individual plutons in the region vary in Th and $U$. In addition, the variation in Th/U ratios within individual plutons are then subsequently caused by fractional crystallization. The Th/U versus $U$ plot shows that the $U$ concentration stays over most of the $\mathrm{Th} / \mathrm{U}$ ratio range relatively low, but at low $\mathrm{Th} / \mathrm{U}$ ratios, the $\mathrm{U}$ concentrations are high. This implies that the Th/U ratios of the Variscan granites are mostly dependent on monazite fractionation, except at low Th/U ratios. Zircon, however, is a major host for $\mathrm{U}$, and thus, fractionation of zircon would also affect the high Th/U ratios. However, the extremely low $\mathrm{Th} / \mathrm{U}$ ratios in the Oberpfalz granites are mainly due to high $\mathrm{U}$ and low Th concentrations. As the Oberpfalz granites have been intruded along fault intersections with the Moldanubian-Saxothuringian suture zone, it is quite possible that the high $U$ concentrations are due to $U$ mobilization. The high $U$ concentrations due to $U$ mobilization have a much higher impact on the depleted samples than a few ppm addition or loss of $U$ would influence samples with higher $U$ and Th concentrations.

The diorites (redwitzites) are less abundant among the igneous rocks in NE Bavaria. They belong to a group of peculiar late-Variscan igneous rocks [102,103]. These diorites have relatively high $\mathrm{Th} / \mathrm{U}$ ratios and Th concentrations, but quite low $\mathrm{U}$ values.

Fichtelgebirge (Region 1)

Within the Fichtelgebirge granites (G1 to G4, e.g., [58], Th/U versus Th ratios show a positive correlation, whereas $\mathrm{Th} / \mathrm{U}$ versus $\mathrm{U}$ shows a trend to higher $\mathrm{U}$ concentrations with low Th/U ratios (Figure 4a,b). This is in agreement with the interpretation of [104] who suggested that the G1 granites (OIC) show a progressive differentiation trend, which could be explained by enhanced fractionation of monazite in relation to zircon.

Siebel et al. [105] suggested that G1 granites have different source compositions. One model for the origin of G1 is a mixing between mantle-derived magmas and Saxothuringian or Moldanubian paragneisses [105]. The G1 magma could have been formed in a subsequent stage with less or no involvement of mantle-derived material. This interpretation 
is supported by this study, as G1 granites have higher Th/U ratios that were internally fractionated (Figure $4 a, b)$.

The G2 and G3 (YIC 1) granites have the same pattern as the OIC granites, except that the G3 and Flossenbürg granites partly show low Th/U ratios and high $U$ concentrations that can be explained by U mobilization or/and fractional crystallization. G2 granites show higher Th/U ratios suggesting that they have fractionated less monazite than G3 granites. Hecht $[106,107]$ suggests that G2 and G3 were formed from the same magma that crystallized in two textural varieties in the course of differentiation. It could be that crystallization at the sides leads to a more differentiated magma inward, from which a new batch can be issued. Alternatively, multiple injections emplace successively from a source differentiated at depth.

G4 granites (YIC-2) have high $U$ concentrations with $T h / U$ ratios $<1$ due to $U$ mobilization and/or fractional crystallization, but lie on a fractionation line together with G2 and G3 granites (Figure 4a,b). Most authors also suggest that the continuous evolution in mineralogy and rock texture, as well as in whole-rock and mineral chemistry from G2\&G3 towards $G 2^{*} \& G 4$ is an indicator for the rocks being related to each other (e.g., [106-109]. However, Siebel et al. [105] suggested, based on $\varepsilon N d(t)$ values, that due to a larger scatter of G4 compared to G2\&G3, a more heterogeneous source or wall-rock contamination is responsible for the heterogeneity. Hecht et al. [107] and Irber et al. [110] state that within the YIC (G2, G3 and G4), autometasomatism increases with increasing differentiation, culminating in the most differentiated samples of G4 $[107,110]$. The high U concentrations in the samples definitely support a late stage metasomatism.

Oberpfalz (Region 2)

Based on chemical and isotopic composition the granites of Leuchtenberg and Zainhammer, are transitional between S- and I-type, whereas those of Falkenberg, Friedenfels, Steinwald and Flossenbürg are S-type granites [64]. Most intrusions display chemical characteristics, which can be explained by fractional crystallization processes [105,108,111,112]. Leuchtenberg and Zainhammer granites show, on average, higher Th/U ratios than the S-type granites, but mostly lower $U$ concentrations (Figure $5 a, b$ ). This suggests that the Zainhammer and Leuchtenberg granites have a source with a considerable higher mantle component and were not or only little affected by U mobilization compared to the S-type granites. Our observation here is supported by $\mathrm{Nd}$ isotopic characteristics of the older granitoids as reported by $[59,113,114]$. These authors suggest a higher degree of contribution from the mantle in the older granites than in the younger granites. Siebel et al. [64] suggested, based on zircon analysis, that magma-generating processes were different for the older granitoids (diorites and older granites) and the two groups of younger granites. The S-type granites of Falkenberg, Friedenfels, Steinwald and Flossenbürg lie on a positive trend plotting $\mathrm{Th} / \mathrm{U}$ ratios versus $\mathrm{Th}$. In the Th versus $\mathrm{U}$ diagram, the samples of each location lie in a separate field. In contrast, $\mathrm{Th} / \mathrm{U}$ ratios versus $\mathrm{U}$ concentrations show that $U$ values stay rather constant, except for high $U$ concentrations (Figure $5 a, b)$. These results show that the different granites show different degrees of fractional fractionation of monazite and in a lesser amount, xenotime and apatite (e.g., [48,100]). In addition, many of the Steinwald and Friedenfels granites were affected by U mobilization. However, high $\mathrm{U}$ concentrations and a decrease in Th contents could also be due to differentiation of the magma (e.g., [48]) and then reflected in the Th/ $\mathrm{U}$ ratios that are $<1$, on average, in these granites. This is also true for some of the granites from Flossenbürg and Falkenberg. Bea et al. $[115,116]$ shows that the strongly peraluminous and P-rich granites from the Pedrobernado pluton, central Spain, are extremely depleted in Th and U due to monazite and apatite fractionation. We suggest that both fractionation of the magmas and source composition are the dominant signatures in the S-type granites of the Variscan Bohemian granites.

Bavarian Forest (Region 3)

According to [117], the Hauzenberg I and II granites belong to the S-type granites which originated by re-melting of the continental crust. The Hauzenberg granodiorite 
contains monazite, but the Hauzenberg I and II S-type granites do not contain significant monazite. Some of the Hauzenberg diorites contain relatively low Th and U concentrations compared to the other granites. This suggests that monazite is not evenly distributed in the granites.

The Fürstenstein diorites have $\mathrm{Sr}$ and $\mathrm{Nd}$ isotope ratios, which suggest mantle contribution to melts or melting of young mafic lower crust [105]. The diorites are isotopically similar to the dioritic rocks, from northern Oberpfalz in NE Bavaria [105]. Zircon data indicate that the diorites are contemporaneous with the granites of the Fürstenstein granite massif and the "older granites" in northern Oberpfalz (Leuchtenberg, Zainhammer granites) $[59,64]$.

\subsection{Average Th/U Ratios of the A-, I-, S-Type Granites}

Our data show that the average Th/U ratios for the S-, A- and I-type granites are significantly different, implying that the $\mathrm{Th} / \mathrm{U}$ ratios are a petrogenetic fingerprint of the sources (Figure 8, Table S3 in the Supplementary Materials). The Th/U ratios of each field overlap with each other and therefore cannot be taken by itself as a definite characteristic. The A-type Malani granites have the highest average Th/U ratios of 6.2 and 8.0, respectively. They are followed by the I-type diorites of the Fichtelgebirge (average Th/U ratio of 4.8) and the Oberpfalz (average Th/U ratio of 6.0) and the diorites from the Bavarian Forest (Hauzenberg average Th/U ratio of 4.6 and Fürstenstein average Th/U ratio of 3.7). Within the Fürstenstein Massif, the high Th concentrations can be explained by a high amount of monazite in this late-stage granite formation [71].

The S- to I-type granites from the Oberpfalz have average Th/U ratios of 3.5 (Zainhammer 2.9 and Leuchtenberg 2.8). The S-type granites from the Fichtelgebirge have average lower Th/U ratios of 2.1 (G2 2.3 and G3 2.0) and the ones from the Oberpfalz of 1.0 (Falkenberg 2.8, Friedenfels 0.7, Steinwald 0.2 and Flossenbürg 0.8); the Hauzenberg granites I and II of 3.2 and 1.8. The tin granite has an average Th/U ratio of 0.5 . The Falkenberg granites have high Th/U ratios due to their high Th concentrations. Most granite intrusions studied here are characterized by $\mathrm{Th} / \mathrm{U}$ ratios $>1$ that can be explained by enriched sources and additionally, fractionation processes. These are all A- and I-type granites. In contrast, the S-type granites show average $T h / U$ ratios $<1$ due to high $U$ concentrations. Our results show that it is possible in a first approach to use the Th/U ratios in order to distinguish between different granite types. Fractionation of the magmas does change the Th/U ratios, but the source composition seems to be the dominant control.

\section{Conclusions}

This is the first systematic Th and U study of S-, A- and I-type granites on a larger scale (550 measurements) with samples from typical settings for I- and S-type (Variscan granites) and A-type Malani (India) granites. The main results of this work can be summarized as follows:

- $\quad$ Average Th/U ratios of A-, I- and S-type granites differ significantly from each other due to the involvement of different sources.

- The Th/U ratios of all four studied regions show a large range between 0.07-12.4 and therefore, a larger range than assumed so far.

- Middle Proterozoic granites are assumed to have Th/U ratios $<10$. However, this study shows that there are middle Proterozoic granites with Th/U ratios $>10$ (A-type granites).

- $\quad$ The A-type Malani granites and the I-type, I-to S-type and S-type Variscan granites from the Fichtelgebirge, Oberpfalz and Bavarian Forest show a large variation in Th and $U$ concentrations, with the A-type granites showing a higher variation in Th than in $U$, whereas S-type granites vary the most in $U$.

- In addition, Th/U ratios within individual regions vary significantly, too.

- A-type Malani granites have the highest average Th/U ratios and high Th concentrations, followed by I-type diorites. 
- S- to I-type granites have lower average Th/U ratios compared to A-type and I-type granites, but higher values than the Bohemian S-type granites.

- $\quad \mathrm{A}-$-, I- and S-type granites all lie on a positive Th/U versus Th trend line, showing that the variation in $T h / U$ ratios is mostly dependent of Th, except in the cases of $U$ mobilization.

- The variation of $\mathrm{Th} / \mathrm{U}$ ratios in all three types of granite cannot be exclusively explained by fractional crystallization of monazite, zircon and other Th- and U-bearing minerals alone, but in the studied plutons, it is probably mostly due to source heterogeneities and $\mathrm{U}$ mobilization processes.

Supplementary Materials: The following are available online at https: / www.mdpi.com/article/ $10.3390 / \min 11070672 / s 1$, Table S1: Th and U concentrations of the A-type, S-type, I-type and SI-type granites from the Fichtelgebirge, Oberpfalz, Bavarian Forest and India (550 samples). All measurements and coordinates of locations are recorded in our previous published papers [74,75], Table S2: Statistical evaluation of the data. Shown here the mean, standard deviation (1 sigma) and the mean square error, Table S3: Statistical analysis using the Mann-Whitney U pairwise test with Bonferroni correction (Past 4.01). Medians of the Th/U ratios differ significantly for all granite types on the $95 \%$ confidence interval, with the exception of the S-I-type and I-type medians, which only differ on the $90 \%$ confidence interval. U concentrations differ significantly for all granite types except the S-I-type and A-type granites. Th concentrations differ significantly for all granite types on the $95 \%$ confidence interval.

Author Contributions: Conceptualization, A.R. and H.D.W.; methodology, L.S.; data curation, L.S.; writing-original draft preparation, A.R. and H.D.W.; writing-review and editing, A.R. and H.D.W.; visualization, A.R. and H.D.W.; supervision, A.R. and H.D.W.; project administration, A.R. and H.D.W. All authors have read and agreed to the published version of the manuscript.

Funding: This research received no external funding.

Data Availability Statement: The data of this publication has already been published in $[74,75,85]$.

Acknowledgments: Gamma radiation data of Variscan granites were acquired during a project funded within the scope of "Bodenatlas Bayern" by the State Bavaria, co-financed by the European Union (EFRE-Program Bayern 2014-2020). Measurements on the Indian Malani granites were obtained during field work funded by the DFG, Germany, grant number Wa 1010/15. We thank K. de Baets for his support with statistical analysis. We also thank L. Xing and two anonymous editors for handling the manuscript and four anonymous reviewers for their comments, which helped to improve the manuscript.

Conflicts of Interest: The authors declare no conflict of interest.

\section{References}

1. Taylor, S.R.; McLennan, S.M. Planetary Crusts: Their Composition and Evolution; Cambridge University Press: Cambridge, UK, 2009; p. 378.

2. Rudnick, R.L.; Gao, S. Composition of the continental crust. In Treasure on Geochemistry. The Crust; Rudnick, R.L., Ed.; Pergamon: New York, NY, USA, 2003; Volume 3, pp. 1-64.

3. Cobbing, J. The Granite Controversy and Its Aftermath. In The Geology and Mapping of Granite Batholiths; Springer: Berlin/Heidelberg, Germany, 2000; pp. 109-115.

4. Young, D.A. Mind over Magma. The Story of Igneous Petrology; Princeton University Press: Princeton, NJ, USA, 2003.

5. Grove, T.L.; Elkins-Tanton, L.T.; Parman, S.W.; Chatterjee, N.; Müntener, O.; Gaetani, G.A. Fractional crystallization and mantle-melting controls on calc-alkaline differentiation trends. Contrib. Mineral. Petrol. 2003, 145, 515-533. [CrossRef]

6. Ulmer, P.; Kaegi, R.; Müntener, O. Experimentally derived intermediate to silica-rich arc magmas by fractional and equilibrium crystallization at 1.0 GPa: An evaluation of phase relationships, compositions, liquid lines of descent and oxygen fugacity. J. Petrol. 2018, 59, 11-58. [CrossRef]

7. Clemens, J.D. S-type granitic magmas-Petrogenetic issues, models and evidence. Earth Sci. Rev. 2003, 61, 1-18. [CrossRef]

8. Clemens, J.D. Granites and granitic magmas: Strange phenomena and new perspectives on some old problems. Proc. Geol. Assoc. 2005, 116, 9-16. [CrossRef]

9. Clemens, J.D.; Stevens, G. What controls chemical variation in granitic magmas? Lithos 2012, 134, 317-329. [CrossRef]

10. Brown, M. Melting of the continental crust during orogenesis: The thermal, rheological, and compositional consequences of melt transport from lower to upper continental crust. Can. J. Earth Sci. 2010, 47, 655-694. [CrossRef] 
11. Brown, M. Granite: From genesis to emplacement. Geol. Soc. Am. Bull. 2013, 125, 1079-1113. [CrossRef]

12. Weinberg, R.F.; Hasalová, P. Water-fluxed melting of the continental crust: A review. Lithos 2015, 212-215, 158-188. [CrossRef]

13. Collins, W.J.; Huang, H.Q.; Jiang, X.Y. Water-fluxed crustal melting produces Cordilleran batholiths. Geology 2016, 44, 143-146. [CrossRef]

14. Yakymchuk, C. On granites. J. Geol. Soc. India 2019, 94, 9-22. [CrossRef]

15. Collins, W.J.; Huang, H.Q.; Bowden, P.; Kemp, A.I.S. Repeated S-I-A-type granite trilogy in the Lachlan Orogen and geochemical contrasts with A-type granites in Nigeria: Implications for petrogenesis and tectonic discrimination. Geol. Soc. 2020, 491, 53-76. [CrossRef]

16. Rudnick, R.L. Making continental crust. Nature 1995, 378, 573-578. [CrossRef]

17. Kelemen, P.B. Genesis of high Mg\# andesites and the continental crust. Contrib. Miner. Pet. 1995, 120, 1-19.

18. Moyen, J.-F.; Laurent, O.; Chelle-Michou, C.; Couzinié, S.; Vanderhaeghe, O.; Zeh, A.; Villaros, A.; Gardien, V. Collision vs. subduction-related magmatism: Two contrasting ways of granite formation and implications for crustal growth. Lithos 2016, 7, 277. [CrossRef]

19. Wedepohl, K.H. Chemical composition and fractionation of the continental crust. Geol. Rundsch. 1991, 80, 207-223. [CrossRef]

20. Hawkesworth, C.J.; Dhuime, B.; Pietranik, A.B.; Cawood, P.A.; Kemp, A.I.S.; Storey, C.D. The generation and evolution of the continental crust. J. Geol. Soc. 2010, 167, 229-248. [CrossRef]

21. Dhuime, B.; Hawkesworth, C.; Cawood, P. When continents formed. Science 2011, 331, 154-155. [CrossRef]

22. Christensen, N.I.; Mooney, W.D. Seismic velocity structure and composition of the continental crust: A global view. J. Geophys. Res. Solid Earth 1995, 100, 9761-9788. [CrossRef]

23. Artemieva, I.A.; Thybo, H.; Jakobson, K.; Sorensen, N.K.; Nielsen, L.S.K. Heat production in granitic rocks: Global analysis based on a new data compilations GRANITE2017. Earth Sci. Rev. 2017, 172, 1-26. [CrossRef]

24. Cherepanova, Y.; Artemieva, I.M.; Thybo, H.; Chemia, Z. Crustal structure of the Siberian craton and the West Siberian basin: An appraisal of existing seismic data. Tectonophysics 2013, 609, 154-183. [CrossRef]

25. Le Maitre, R.W. The chemical variability of some common igneous rocks. J. Petrol. 1976, 17, 589-637. [CrossRef]

26. Le Maitre, R.W. A classification of igneous rocks and glossary of terms. In Recommendations of the International Union of Geological Sciences Subcommission on the Systematics of Igneous Rocks; Cambridge University Press: Cambridge, UK, 1989 ; Volume 193.

27. Streckeisen, A. To each plutonic rock its proper name. Earth Sci. Rev. 1976, 12, 1-33. [CrossRef]

28. Shand, S.J. On the relations between silica, alumina, and the bases in eruptive rocks, considered as a means of classification. Geol. Mag. 1927, 64, 446-449. [CrossRef]

29. Shand, S.J. The Eruptive Rocks, 2nd ed.; John Wiley: New York, NY, USA, 1943; 444p.

30. Chappell, B.W.; White, A.J.R. I-and S-type granites in the Lachlan Fold Belt. Earth Environ. Sci. Trans. R. Soc. Edinb. 1992, 83, 1-26.

31. Chappell, B.W.; White, A.J.R. Two contrasting granite types: 25 years later. Aust. J. Earth Sci. 2001, 48, 489-499. [CrossRef]

32. Pearce, J. Sources and settings of granitic rocks. Episodes 1996, 19, 120-125. [CrossRef]

33. Winter, J.D. An Introduction to Igneous and Metamorphic Petrology; Prentice Hall: Hoboken, NJ, USA, 2001.

34. Bonin, B. A-type granites and related rocks: Evolution of a concept, problems and prospects). Lithos 2007, 97, 1-29. [CrossRef]

35. Grapes, R.; Chen, G.-N. Granite Genesis: In-Situ Melting and Crustal Evolution; Springer: Amsterdam, The Netherlands, 2007.

36. Winter, J.D. Principles of Igneous and Metamorphic Petrology, 2nd ed.; Pearson: London, UK, 2010.

37. Castro, A.; Moreno-Ventas, I.; De Le Rosa, J.D. H (Hybrid)-type granitoids: A proposed revision of the granite-type classification and nomenclature. Earth Sci. Rev. 1991, 31, 237-253. [CrossRef]

38. Kilpatrick, J.A.; Ellis, D.J. C-type magmas: Igneous charnockites and their extrusive equivalents. Trans. R. Soc. Edinb. Earth Sci. 1992, 83, 155-164.

39. Frost, B.R.; Barnes, C.G.; Collins, W.J.; Arculus, R.J.; Ellis, D.J.; Frost, C.D. A geochemical classification for granitic rocks. J. Petrol. 2001, 42, 2033-2048. [CrossRef]

40. Jaupart, C.; Mareschal, J.C. Constraints on crustal heat production from heat flow data. In Treatise on Geochemistry; Holland, H.D., Turekian, K.K., Eds.; Elsevier-Pergamon: Oxford, UK, 2003; Volume 4, pp. 65-84.

41. Vilà, M.; Fernández, M.; Jiménez-Munt, I. Radiogenic heat production variability of some common lithological groups and its significance to lithospheric thermal modeling. Tectonophysics 2010, 490, 152-164. [CrossRef]

42. Bea, F.; Monero, P.; Zinger, T. The Nature, Origin, and Thermal Influence of the Granite Source Layer of Central Iberia. J. Geol. 2003, 111, 579-595. [CrossRef]

43. Wark, D.A.; Miller, C.F. Accessory mineral behavior during differentiation of a granite suite: Monazite, xenotime and zircon of the Sweetwater Wash pluton, southeastern California, USA. Chem. Geol. 1993, 110, 49-67. [CrossRef]

44. Marchalland, C.P.; Fairbridge, R.W. Encyclopedia of Geochemistry; Kluwer Academic Press: London, UK, 1999.

45. Van Schmus, W.R. Natural radioactivity of the crust and mantle. In Global Earth Physics. A Handbook of Physical Constants; AGU Reference Shelf: Washington, DC, USA, 1995; Volume 1, pp. 283-293.

46. Champion, D.C.; Chappell, B.W. Petrogenesis of felsic I-type granites: An example from northern Queensland. Trans. R. Soc. Edinb. Earth Sci. 1992, 83, 115-126.

47. Villaseca, C.; Barbero, L.; Rogers, G. Crustal origin of Hercynian peraluminous granitic batholiths of Central Spain: Petrological, geochemical and isotopic ( $\mathrm{Sr}, \mathrm{Nd}$ ) constraints. Lithos 1998, 43, 55-79. [CrossRef] 
48. Pérez-Soba, C.; Villaseca, C.; Orejana, D.; Jeffries, T. Uranium-rich accessory minerals in the peraluminous and perphosphorous Belvís de Monroy pluton (Iberian Variscan belt). Contrib. Mineral. Petrol. 2014, 167, 1008. [CrossRef]

49. Taylor, S.R.; McLennan, S.M. The Continental Crust: Its Composition and Evolution; U.S. Department of Energy Office of Scientific and Technical Information: Oak Ridge, TN, USA, 1985.

50. Rudnick, R.L.; McDonough, W.F.; O'Connell, R.J. Thermal structure, thickness and composition of continental lithosphere. Chem. Geol. 1998, 145, 395-411. [CrossRef]

51. McLennan, S.M. Relationship between the trace element composition of sedimentary rocks and upper continental crust. Geochem. Geophy. Geosy. 2001, 2, 70-73. [CrossRef]

52. Kemp, A.I.S.; Hawkesworth, C.J. Treatise on Geochemistry; The Crust; Elsevier: Oxford, UK, 2003; Volume 3.

53. Wedepohl, K.H. The composition of the continental crust. Geochim. Cosmochim. Acta 1995, 59, 1217-1232. [CrossRef]

54. Arevalo, R., Jr.; McDonough, W.F.; Luong, M. The K/U ratio of the silicate Earth: Insights into mantle composition, structure and thermal evolution. Earth Planet. Sci. Lett. 2009, 278, 361-369. [CrossRef]

55. Hacker, B.R.; Kelemen, P.B.; Behn, M.D. Differentiation of the continental crust by relamination. Earth Planet. Sci. Lett. 2011, 307, 501-516. [CrossRef]

56. Andersen, M.B.; Elliott, T.; Freymuth, H.; Sims, K.W.; Niu, Y.; Kelley, K.A. The terrestrial uranium isotope cycle. Nature 2015, 517, 356. [CrossRef]

57. Bea, F.; Montero, P. Behavior of accessory phases and redistribution of Zr, REE, Y, Th, and U during metamorphism and partial melting of metapelites in the lower crust: An example from the Kinzigite Formation of Ivrea-Verbano, NW Italy. Geochim. Cosmochim. Acta 1999, 63, 7-8. [CrossRef]

58. Hecht, L.; Vigneresse, J.L.; Morteani, G. Constraints on the origin of zonation of the granite complexes in the Fichtelgebirge (Germany and Czech Republic): Evidence from a gravity and geochemical study. Geol. Rundsch. 1997, 86 (Suppl. 1), 93-109. [CrossRef]

59. Siebel, W.; Trzebski, R.; Stettner, G.; Hecht, L.; Casten, U.; Höhndorf, A.; Müller, P. Granitoid magmatism of the NW Bohemian massif revealed: Gravity data, composition, age relations and phase concept. Geol. Rundsch. 1997, 86, 45-63. [CrossRef]

60. Fornelli, A.; Caggianelli, A.; Del Moro, A.; Bargossi, G.M.; Paglionico, A.; Piccarreta, G.; Rottura, A. Petrology and evolution of the Central Serre Granitoids (southern Calabria-Italy). Period. Mineral. 1994, 63, 53-70.

61. Fornelli, A. Metamorphic xenoliths and microgranular enclaves in the Serre granodiorites (southern Calabria-Italy): Their connection with granitoid genesis. Mineral. Petrol. 1994, 51, 49-65. [CrossRef]

62. Roda-Robles, E.; Villaseca, C.; Pesquera, A.; Gil-Crespo, P.P.; Vieira, R.; Lima, I.; Garate-Olave, I. Petrogenetic relationships between Variscan granitoids and Li-(F-P)-rich aplite-pegmatites in the Central Iberian Zone: Geological and geochemical constraints and implications for other regions from the European Variscides. Ore Geol. Rev. 2018, 95, 408-430. [CrossRef]

63. Bea, F.; Montero, P.; Molina, J.F. Mafic precursors, peraluminous granitoids, and late lamprophyres in the Avila batholith: A model for the generation of Variscan batholiths in Iberia. J. Geol. 1999, 107, 399-419. [CrossRef]

64. Siebel, W.; Chen, F.; Satir, M. Late-Variscan magmatism revisited: New implications from Pb-evaporite zircon ages on the emplacement of redwitzites and granites in NE Bavaria. Int. J. Earth Sci. 2003, 92, 36-53. [CrossRef]

65. Siebel, W.; Chen, F. Zircon Hf isotope perspective on the origin of granitic rocks from eastern Bavaria, SW Bohemian Massif. Int. J. Earth Sci. 2010, 99, 993-1005. [CrossRef]

66. Kováŕíková, P.; Siebel, W.; Jelínek, E.; Štemprok, M.; Kachlík, V.; Holub, F.V.; Blecha, V. Petrology, geochemistry and zircon age for redwitzite at Abertamy, NW Bohemian Massif (Czech Republic): Tracing the mantle component in Late Variscan intrusions. Chem. Erde Geochem. 2007, 67, I151-I174. [CrossRef]

67. Schulmann, K.; Konopásek, J.; Janoušek, V.; Lexa, O.; Lardeaux, J.M.; Edel, J.B.; Štípská, P.; Ulrich, S. An Andean type Palaeozoic convergence in the Bohemian Massif. Comptes Rendus Geosci. 2009, 341, 266-286. [CrossRef]

68. Kalt, A.; Corfu, F.; Wijbrans, J.R. Time calibration of a P-T path from a Variscan high-temperature low-pressure metamorphic complex (Bayerischer Wald, Germany) and the detection of inherited monazite. Contrib. Mineral. Petrol. 2000, 138, 143-163. [CrossRef]

69. Klein, T.; Kiehm, S.; Siebel, S.; Shang, C.K.; Rohrmüller, J.; Dörr, W.; Zulauf, G. Age and emplacement of late-Variscan granites of the western Boheminan Massif with main focus on the Hauzenberg granitoids (European Variscides, Gemany). Lithos 2008, 102, 478-507. [CrossRef]

70. Siebel, W.; Shang, C.K.; Thern, E.; Danišík, M.; Rohrmüller, J. Zircon response to high-grade metamorphism as revealed by U-Pb and cathodoluminescence studies. Int. J. Earth Sci. 2012, 101, 2105-2123. [CrossRef]

71. Chen, F.; Siebel, W. Zircon and titanite geochronology of the Fürstenstein granite massif, Bavarian Forest, NW Bohemian Massif: Pulses of the late Variscan magmatic activity. Eur. J. Mineral. 2004, 16, 777-778. [CrossRef]

72. Siebel, W.; Blaha, U.; Chen, F.; Rohrmüller, J. Geochronology and geochemistry of a dyke-host rock association and implications for the formation of the Bavarian Pfahl shear zone, Bohemian Massif. Int. J. Earth Sci. 2005, 94, 8-23. [CrossRef]

73. Finger, F.; Gerdes, A.; René, M.; Riegler, G. The Saxo-Danubian Granite Belt: Magmatic response to post-collisional delamination of mantle lithosphere below the southwestern sector of the Bohemian Massif (Variscan orogen). Geol. Carpathica 2009, 60, 205-212. [CrossRef]

74. Scharfenberg, L.; de Wall, H. Natürliche Gammastrahlung von Graniten in der Oberpfalz (Nordost-Bayern)—Vergleich von aerogeophysikalischen und in situ-gammasprectroskopischen Messungen. Geol. Blätter Nordost-Bayern 2016, 66, $205-227$. 
75. Scharfenberg, L.; Regelous, A.; de Wall, H. Radiogenic heat production of Variscan granites from the Western Bohemian Massif, Germany. J. Geosci. 2019, 64, 251-269. [CrossRef]

76. Gregory, L.C.; Meert, J.G.; Bingen, B.; Pandit, M.K.; Torsvik, T.H. Paleomagnetism and geochronology of the Malani Igneous Suite, Northwest India: Implications for the configuration of Rodinia and the assembly of Gondwana. Precambrian Res. 2009, 170, 13-26. [CrossRef]

77. Pareek, H.S. Pre-Quaternary geology and mineral resources of Northwestern Rajasthan. Geol. Surv. India Mem. 1984, 115, 99.

78. Bhushan, S.K. Malani rhyolites-A review. Gondwana Res. 2000, 3, 65-77. [CrossRef]

79. De Wall, H.; Pandit, M.K.; Dotzler, R.; Just, J. Cryogenian transpression and granite intrusion along the western margin of Rodinia (Mt. Abu region): Magnetic fabric and geochemical inferences on Neoproterozoic geodynamics of the NW Indian block. Tectonophysics 2012, 554, 143-158. [CrossRef]

80. Shakoor, M.A.; Yang, X.; Deng, J.; Hakro, A.A.A.D. Early Neoproterozoic evolution of Southeast Pakistan: Evidence from geochemistry, geochronology and isotopic composition of the Nagarparkar Igneous Complex. Int. Geol. Rev. 2018, 61, 1398-1408.

81. Gupta, S.N.; Arora, Y.K.; Mathur, R.K.; Iqballaddin Prasad, B.; Sahai, T.N.; Sharma, S.B. The Precambrian Geology of the Aravalli Region. Southern Rajasthan and Northeastern Gujarat. Mem. Geol. Surv. India 1997, 123, 262.

82. De Wall, H.; Regelous, A.; Schulz, B.; Hahn, G.; Bestmann, M.; Sharma, K. Neoproterozoic geodynamics in NW India-Evidence from Erinpura granites in the South Delhi Fold Belt. Int. Geol. Rev. 2021. [CrossRef]

83. Eby, G.N.; Kochhar, N. Geochemistry and petrogenesis of the Malani Igneous Suite, northern India. J. Geol. Soc. India 1990, 36, 109-130.

84. Vallinayagam, G.; Singh, L.G. Radioactive Heat Producing felsic to intermediate volcano-plutonic rocks of Dhiran Area, Malani Igneous Suite, Western India. Earth Sci. India 2011, 4, 76-78.

85. Scharfenberg, L.; Jandausch, S.; Anetzberger, L.; Regelous, A.; Sharma, K.K.; de Wall, H. Differences in natural gamma radiation characteristics of Erinpura and Malani granite in NW India. J. Earth Syst. Sci. 2019, 128, 137. [CrossRef]

86. Ashwal, L.D.; Solanki, A.M.; Pandit, M.K.; Corfu, F.; Hendriks, B.W.H.; Burke, K.; Torsvik, T.H. Geochronology and geochemistry of Neoproterozoic Mt. Abu granitoids, NW India: Regional correlation and implications for Rodinia paleogeography. Precambrian Res. 2013, 236, 265-281. [CrossRef]

87. Grasty, R.L.; Holman, P.B.; Blanchard, Y.B. Transportable calibration pads for ground and airborne gamma-ray spectrometers. Geol. Surv. Can. 1991, 90, 25p.

88. Sun, S.S.; McDonough, W.F. Chemical and isotopic systematics of oceanic basalts: Implications for mantle composition and processes. Geol. Soc. 1989, 42, 313-345. [CrossRef]

89. Merino, E.; Villaseca, C.; Orejana, D.; Jeffries, T. Gahnite, chrysoberyl and beryl co-occurrence as accessory minerals in a highly evolved peraluminous pluton: The Belvís de Monroy leucogranite (Cáceres, Spain). Lithos 2013, 179, 137-156. [CrossRef]

90. Adams, A.S.; Osmond, J.K.; Rogers, J.J.W. The geochemistry of thorium and uranium. Phys. Chem. Earth 1959, 3, 298-348. [CrossRef]

91. Bea, F. The sources of energy for crustal melting and the geochemistry of heat-producing elements. Lithos 2012, 153, 278-291. [CrossRef]

92. Wasserburg, G.J. Pb-U-Th evolution models for homogeneous systems with transport. Trans. Am. Geophys. Union 1964, 45, 111.

93. Whalen, J.B. Geochemistry of an island-arc plutonic suite: The Uasilau-Yau Yau intrusive complex, New Britain. PNG J. Petrol. 1985, 26, 603-632. [CrossRef]

94. Bültemann, H.W. Die Uranvorkommen im ostbayerischen Grundgebirge Raum Maehring, Krs. Tirschenreuth Opf Zeitschrift Deutschen Geologischen Gesellschaft 1979, 130, 575-596. [CrossRef]

95. Stettner, G. Der Grenzbereich Saxothuringikum-Moldanubische Region im Raum Tirschenreuth-Maehring (Oberpfalz) und die Situation des Uran-führenden Präkambriums. Zeitschrift Deutschen Geologischen Gesellschaft 1979, 130, 561-574. [CrossRef]

96. Dill, H.; Weiser, T. Eine Molybdaensulfid-Impsonit-Mineralisation aus dem Uranvorkommen Waeldel/Maehring (Oberpfalz). Neues Jahrbuch für Mineralogie Monatshefte 1981, 5, 452-458.

97. Whitfield, J.M.; Rogers, J.J.W.; Adams, J.A.S. The relationship between the petrology and the thorium and uranium contents of some granitic rocks. Geochim. Cosmochim. Acta 1959, 17, 248-271. [CrossRef]

98. Buntebarth, G. Distribution of uranium in intrusive bodies due to combined migration and diffusion. Earth Planet. Sci. Lett. 1976, 32, 84-90. [CrossRef]

99. Papadopoulos, A.; Christofides, G.; Koroneos, A.; Papastefanou, C.; Stoulos, S. Distribution of 238U, 232Th and 40K in plutonic rocks of Greece. Chem. Erde Geochem. 2014, 74, 749-764. [CrossRef]

100. Pérez-Soba, C.; Villaseca, C.; Fernández, A. Magmatic graphite inclusions in Mn-Fe-rich fluorapatite of perphosphorus granites (the Belvís pluton, Variscan Iberian Belt). Am. Mineral. 2017, 102, 728-742. [CrossRef]

101. Breiter, K. Monazite and zircon as major carriers of Th, $\mathrm{U}$, and $\mathrm{Y}$ in peraluminous granites: Examples from the Bohemian Massif. Mineral. Petrol. 2016, 110, 767-785. [CrossRef]

102. Fischer, G. Über die modale Zusammensetzung der Eruptiva im ostbayerischen Kristallin. Geol. Bavarica 1965, 55, 7-33.

103. Troll, G. Das Intrusivgebiet von Fürstenstein (Bayerischer Wald). Geol. Bavarica 1964, 52, 1-140.

104. Friedrich, M.H.; Cuney, M.; Poty, B. Uranium geochemistry in peraluminous leucogranites. Uranium 1987, 3, $353-385$.

105. Siebel, W.; Höhndorf, A.; Wendt, I. Origin of late Variscan granitoids from NE Bavaria, Germany, exemplified by REE and Nd isotope systematics. Chem. Geol. 1995, 125, 249-270. [CrossRef] 
106. Hecht, L. Die Glimmer als Indikatoren für die magmatische und postmagmatische Entwicklung der Granite des Fichtelgebirges (NE Bayern). Münchner Geologische Hefte 1993, 10, 221.

107. Hecht, L. The Chemical Composition of Biotite as an Indicator of Magmatic Fractionation and Metasomatism in Sn-Specialised Granites of the Fichtelgebirge (NW Bohemian Massif, Germany); Kämpf, S., Möller, Eds.; Metallogeny of Collisional Orogens, Czech Geological Survey: Prague, Czech Republic, 1994; pp. 295-300.

108. Richter, P.; Stettner, G. Geochemische und petrographische Untersuchungen der Fichtelgebirgsgranite. Geol. Bavarica 1979, 78, $144 \mathrm{~S}$.

109. Carl, C.; Wendt, I. Radiometrische Datierung der Fichtelgebirgsgranite. Zeitschrift geologische Wissenschaften 1993, $21,49$.

110. Irber, W.; Förster, H.J.; Hecht, L.; Möller, P.; Morteani, G. Experimental, geochemical, mineralogical and O-isotope constraints on the late-magmatic history of the Fichtelgebirge granites (Germany). Geologische Rundschau 1997, 86 (Suppl. 1), 110. [CrossRef]

111. Madel, J. Geochemical structures in a multiple intrusion granite massif. N. Jb. Mineral. Abh. 1975, 124, $103-127$.

112. Wendt, I.; Ackermann, H.; Carl, C.; Kreuzer, H.; Muller, P.; Stettner, G. Rb/Sr-Gesamtgesteins- und K/Ar-Glimmerdatierungen der Granite von Flossenburg und Barnau. Geologisches Jahrbuch 1994, E51, 3-29.

113. Janoušek, V.; Rogers, G.; Bowes, D.R. Sr-Nd isotopic constraints on the petrogenesis of the Central Bohemian Pluton, Czech Republic. Geologische Rundschau 1995, 84, 520-534. [CrossRef]

114. Gerdes, A.; Wörner, G.; Henk, A. Post-collisional granite generation and HT-LP metamorphism by radiogenic heating: The Variscan South Bohemian Batholith. J. Geol. Soc. 2000, 157, 577-587. [CrossRef]

115. Bea, F. Aluminousity-Dependent Fractionation Patterns in Differentiated Granite-Leucogranite Systems; Abstract EOS 74 (16) 343; American Geophysical Society: San Francisco, CA, USA, 1993.

116. Bea, F.; Pereira, M.D.; Corretgé, L.G.; Fershtater, G.B. Differentiation of strongly peraluminous, perphosphorus granites: The pedrobernardo pluton, central Spain. Geochim. Cosmochim. Acta 1994, 58, 2609-2627. [CrossRef]

117. Pitcher, W.S. Granite type and tectonic environment. In Proceedings of the Symposium on Mountain Building, Princeton, NJ, USA, 9-12 May 1983; pp. 19-40. 